\title{
The Challenge Of Student Assessment In The Online Classroom
}

Jane Whitney Gibson, (E-mail: jwgibson1@aol.com), Nova Southeastern University

Charles W. Blackwell, (E-mail: Charlie@huizenga.nova.edu), Nova Southeastern University

\begin{abstract}
With the proliferation of online instruction, questions have arisen regarding the challenges of meaningful student assessment in the online classroom. This paper examines that concern using the literature and the observations of a panel of faculty experts who exhibit various levels of concern about cheating and plagiarism in the online classroom. Suggestions are offered as to how to overcome these challenges. The authors conclude with recommendations including the strategic use of unique frequent opportunities for assessment.
\end{abstract}

\section{INTRODUCTION}

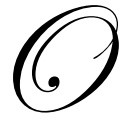

nline instruction is everywhere. High school students take advantage of both part time and full time offerings. One large-scale example, the Florida Virtual School, boasts double digit annual increases for the past five years. (PR Newswire, 2006). It operates as a supplemental program with students averaging 1.7 courses. Other schools such as the Arkansas Virtual School offer only a full-time program. (Greenway. 2006)

In Corporate America, online training programs are more and more apparent as evidenced by the training providers which have proliferated in recent years. One of these companies, Knowledge Net was started in 1998 and boasted 7200 clients by 2003 including such luminaries as Cisco and MacDonald's. (Cooper, 2003).

The place, however, where the most growth in online education is evident and the subject of the current article is in post-secondary education. The numbers of online courses being offered in American universities has exploded since 2000 when the total number doubled in just one year. (BBC News, 2000)

With this significant growth came many administrative, academic, and operational issues about online classes. These include technical support, faculty training, library resources, course platform, issues of intellectual property and teaching pedagogy. In the experience of the authors, one of the most nagging issues is that of the integrity of student assessment in the online environment. Are the skeptics who refuse to take their classes online correct about the potential of rampant cheating in online classes? Is the landscape of academic integrity issues different in cyber classes than in traditional classes? Are there ways in which these issues can be minimized in elearning?

The authors of this article are senior business professors at a large private institution in the Southeastern United States. Their network of colleagues includes eight online professors who have contributed their perceptions to this study. All are early adopters, meaning that they have been teaching online classes since the mid 90s in a variety of settings at the undergraduate and graduate levels. While there is no scientific proof that their experiences are typical, there is every reason to believe that their anecdotal observations can be helpful to others considering the move to cyberspace.

Before examining the issue of assessment integrity in cyberspace, we start by looking at what many consider the epidemic of cheating in American colleges and universities today. 


\section{THE WIDESPREAD ISSUE OF ACADEMIC INTEGRITY}

Cheating is not a subject confined to online classes. By 1999, the cover story of U.S. News \& World Reports, "The Cheating Game," clearly identified the problem. (Kleiner \& Lord, 1999) The authors of this muchquoted article cited studies that showed that $75 \%$ of college students admitted to having cheated at one time or another. Methods include not only the traditional peeking at your neighbor's paper, but sending text messages during exams, lifting sections or entire papers from the Internet, and altering grades after hacking into school databases.

Of all the reasons given why people cheat, including lack of time, fear of failure, desire to get good grades, peer pressure, parental pressure, procrastination, and laziness, perhaps the most disturbing reason is because students feel they can get away with it.

Most cheaters don't get caught. In fact, perhaps the major reason students cheat is that they get away with it, time and time again. Numerous studies say that students almost never squealon a classmate who cheats. And most instructors just don't want to play cop. (Kleiner \& Lord, 1999, para. 27)

More recent studies have also shown that cheating and plagiarism is a college phenomenon in which the majority of students have engaged at one time or another in their college careers. (Gibson, Blackwell, Greenwood, Mobley \& Blackwell, 2006; McCabe, D. L., 2005)

The authors have never yet to meet a faculty member who doesn't agree that cheating is a significant problem in colleges and universities today. Is it realistic to think that there are even more problems with online student assessment?

\section{ACADEMIC INTEGRITY IN ONLINE ASSESSMENT}

When confronting the question of whether plagiarism, cheating, and academic integrity in general are more a problem in online classes as compared to traditional classes, there are perspectives.

The first perspective is that online classes are more likely to be compromised by academic integrity issues. The authors find that one of the most common reasons that some faculty resist teaching online is their perception that the experience is tainted by these academic integrity questions. They feel if they can't actually see the student, they are not sure whose work they are grading. This point-of-view seems to ignore the fact that students have been using "ringers" to take their tests for decades at large universities where classes of 100 and more are not uncommon. Furthermore, there are many other ways that in-class students can cheat on exams. These include crib sheets, copying, passing notes, sending text messages, writing answers on clothing or body parts, developing codes to designate answers to their friends also taking the test, etc. (Olt, 2002)

Neil Rowe from the U.S. Naval Postgraduate School echoes these concerns and posits that it is often easier to cheat online than many faculty realize. He cautions that many online students are far more computer savvy than their online faculty and likens the issue of "educational security" to that of any other type of information security on the Web. Specific examples cited by Rowe include getting assessment answers in advance, logging in as the instructor and reading the answer key, using spyware to see how other students are answering questions, manipulating the system to be able to retake tests, and, of course, using unauthorized people to help you on the test. (Rowe, 2004)

A second perspective is that while the types of academic integrity issues may differ, there is no significant difference in the amount of academic integrity infractions in the online classroom as compared to the onground class. A study by Grijalva (2006) found that academic dishonesty was no more pervasive in an online class than in a traditional class. A survey of 796 students resulted in finding the probability of cheating in one format as compared to the other was not statistically different. The study concludes that there is no reason to suspect "that academic dishonesty will become more common" as online course offerings expand. They suggest the following three 
reasons: (1) There is no proof that the lack of face-to-face supervision deters cheating; (2) There is less opportunity for unplanned, panic cheating in the online environment, and (3) Wary online faculty design assessment tools to reduce the possibility of cheating.

The third point-of-view directly counters the contention that there are more academic integrity issues in cyberspace by suggesting that there is actually less cheating and plagiarism in online classes. Heberling (2002) makes the case that "by the very nature of online education... it is more conducive to both detecting and combating plagiarism than a traditional class." (para 1). He cites the multiple assessment tools used in his masters program at a large private institution in the Midwest and discounts the possibility of someone else sitting in for the student.

Every online course... has a significant discussion component in addition to term papers, case evaluations and exams. Under these conditions, it would be very difficult for a surrogate student to complete an online course, or even a portion of one, given the inter-relatedness of all the activities and extensive on-going time commitment that is required.

Roach (2001) cites Dr. Wallace Pond, chief of academic affairs of Education America Online, as asserting that relatively small online classes and the multiple writing assignments common in online classes give faculty a better knowledge of their students and their writing styles.

Higher education officials believe high online interactivity can act as a safeguard against students who are inclined to submit work that is not their own. If an instructor is using threaded discussions, short papers, live chat sessions and other forms of interactive online instruction, it's possible for that instructor to develop a strong sense of an individual's writing style and thinking. (para 12)

An important part of this study was to go to the trenches and ask well-seasoned online instructors what they think about academic integrity issues in their online classes and how they go about assuring valid student assessment.

\section{A PANEL OF EXPERTS SPEAKS OUT}

Eight seasoned online professors were interviewed on the topic of the challenge of student assessment in the online classroom. All but one are on the business faculty of 4 private universities in Florida and Michigan. The eighth is a faculty member at a major public university in Florida. The majority have participated in numerous conferences on the subject of online education and presented and published papers and articles in the field. Figure 1 provides a summary of the number of online classes they have completed, the levels of these classes and whether or not they are "more," "less," or equally concerned about academic integrity in their online classes as compared to their traditional classes.

Figure 1

\section{The Panel of Experts}

\begin{tabular}{|c|c|c|c|}
\hline Professor & \# of classes taught online & Level of online classes & $\begin{array}{c}\text { More, less or equal concern about } \\
\text { academic integrity }\end{array}$ \\
\hline$\# 1$, male & 10 & Masters & More \\
\hline$\# 2$, female & 20 & U/G & More \\
\hline$\# 3$, male & 30 & Masters & More \\
\hline$\# 4$, female & 50 & Masters & Same \\
\hline$\# 5$, male & 70 & Masters & Same \\
\hline$\# 6$, male & 80 & U/G, Masters & Same \\
\hline$\# 7$, male & $100+$ & Masters & \\
\hline$\# 8$, male & 150 & U/G, Masters & . \\
\hline
\end{tabular}

Note that the 8 respondents are more or less divided among the 3 perspectives detailed above in that they are widely dispersed in their opinion about the incidence of academic integrity challenges in the online environment. Interestingly, it is the 3 most experienced online instructors who assess that challenge as being the same in both their traditional and online classes. 
The question was asked as to the type of assessment tools used in traditional classes versus online classes and in 5 cases the professors responded that they used the same assessment tools in both formats. Professor \# 1 claimed that he used more active discussion in his onground classes, but more papers and fewer quizzes in the online equivalent classes. Professor \# 2 cited case studies, article summaries, and research papers in both types of classes but added exams only to the onground class. Professor \# 4 also relied more on projects in the online class as opposed to case studies and short assignments onground. She indicated that she gave timed midterms and finals in both modes. Professor \# 6 cited all the same assessment techniques with the addition of graded discussion postings in the online classes.

When the question was asked about what measures these individuals took to minimize cheating in their traditional classes versus online classes, some differences were noted as shown in Figure 2.

Figure 2

\section{Measures Taken to Minimize Cheating}

\begin{tabular}{|c|c|c|}
\hline Professor & Traditional Classes & Online Classes \\
\hline$\# 1$, male & Scrambled questions, seating & Timed exams, turnitin.com \\
\hline \#2 female & No longer teaching onground & $\begin{array}{l}\text { Evaluate student writing styles, require } \\
\text { documentation of all sources, } \\
\text { Turnitin.com }\end{array}$ \\
\hline$\# 3$, male & $\begin{array}{l}\text { Up front discussion of zero tolerance, } \\
\text { clear definition of plagiarism }\end{array}$ & $\begin{array}{l}\text { Sometimes use timed exams; same } \\
\text { emphasis on academic integrity }\end{array}$ \\
\hline \#4, female & $\begin{array}{l}\text { Monitored exams, turnitin.com for } \\
\text { papers }\end{array}$ & $\begin{array}{l}\text { Essay exams, projects replace term } \\
\text { papers, timed exams but open book, } \\
\text { open note }\end{array}$ \\
\hline \# 5, male & $\begin{array}{l}\text { Essays, short papers, quizzes, team } \\
\text { projects, presentations, final exams, } \\
\text { case studies }\end{array}$ & All the same assessment techniques. \\
\hline \# 6, male & $\begin{array}{l}\text { Randomized testing, plagiarism } \\
\text { software }\end{array}$ & $\begin{array}{l}\text { Same plus comparison of writing styles } \\
\text { between discussions and papers }\end{array}$ \\
\hline \#7, male & Observation & Honor system \\
\hline$\# 8$, male & $\begin{array}{l}\text { Scrambled questions, plagiarism } \\
\text { software }\end{array}$ & Same \\
\hline
\end{tabular}

Note that professors 2 and 6 mentioned that they use the frequent written assignments of the online environment to become more familiar with each student's writing style and therefore feel better able to spot questionable submissions.

Perhaps the most useful question asked to this cadre of experts is what advice they have for other online instructors to decrease the incidence of cheating and plagiarism in the online classroom.

\section{Maintaining Academic Integrity in Online Classes}

Figure 3 provides specific advice given by our panel of experts and the number of professors who recommended each alternative.

While a diversity of advice was given to meet the challenge of online assessment integrity, the authors particularly liked one strategy used by Professor \# 5. Note that his comments apply to a 10 week MBA class. 
Figure 3

Recommendations to Decrease Cheating and Plagiarism Online

\begin{tabular}{|l|}
\hline Break up major assignments into smaller pieces \\
\hline Require students to write about course-specific topics \\
\hline Discuss research papers individually with students \\
\hline Require copies of sources used in assignments \\
\hline Require initial outlines and drafts \\
\hline Use discussion type questions, not those that require memorization \\
\hline More frequent quizzes and exams \\
\hline Clearly define your policy on cheating and plagiarism (n=3) \\
\hline Have students sign a statement that they will adhere to the no tolerance cheating policy \\
\hline Use plagiarism software \\
\hline Randomized testing \\
\hline Compare writing styles with papers (n=2) \\
\hline Do not provide correct answers to test questions to prevent development of test banks \\
\hline Require group assignments \\
\hline Develop assignments that require students to incorporate their own experiences \\
\hline Add specific, unique requirements to your assignments \\
\hline Multiple assignments, not just midterm and final. \\
\hline Provide feedback throughout the term \\
\hline Make assignments incremental, building on each other. \\
\hline
\end{tabular}

Have a number of small projects to grade and provide feedback for students throughout the term. Build on their small successes each week and ask them to integrate their weekly contribution to their comprehensive term project. For example, students should select their term project title on the second week, present a book summary to the class that relates to their term project on the fourth week, present a recently published journal article that relates to their term project, and do a presentation on the seventh week about their findings thus far and what else they are planning to gather, and finally submit the comprehensive term project (which includes all of their previously completed work) at the last week of the class. Each step of their work is a graded activity....This methodology has proven to be a great means of reducing cheating in the classroom as students take ownership of the topic and move forward one step at a time. (Mujtaba, 2006, personal communication)

\section{CONCLUSION}

There is no conclusive proof that assessment of online classes is substantially more challenging than assessing any other kind of classes. Cheating and plagiarism exist in significant quantity to be worrisome to all faculty in all modes of instruction. The authors do not, however, believe that the challenges of online assessment are any more serious than that of onground classes. They are just different. Nor do we agree with Rowe (2004) who concludes that in order to assure academic honesty, "traditional one-location one-time face-to-face testing for much of the student's grade will need to be the assessment norm for distance learning in the foreseeable future." (para. 39) This requirement undermines the all important convenience factor of online education and once again takes away accessibility from all but local students.

In conclusion, we would like to make the following recommendations to use in crafting online assessments, paying close attention to the challenges of assuring academic integrity.

First, one must assume that online students have their books, notes, and any other resources available to them when they are doing tests and other assignments. The assignments, therefore, should be of a higher level of application and integration so that they can demonstrate mastery of the material. While multiple choice tests which are automatically graded by the online software may be easy to administer, we do not recommend them except for relatively small parts of the grade and then only when there are several of them spaced throughout the course.

One of the authors uses an alternative exam which provides to the student a mock exam already answered by a "pretend" student. The online student's job is to first decide whether each answer is correct or incorrect and then to 
write a paragraph saying why. This allows them to demonstrate far more synthesis of information and learning than a standard, objective test.

Second, there should be more grading points in the online class than in the traditional class. Instead of just a midterm, final, and term paper, online classes typically have weekly discussion questions and grades for a certain amount of participation in synchronous chat rooms and/or asynchronous discussion boards. The authors, for example, require 4-5 days of significant participation each week from each student. This results in far more credit being given for participation than in the average face-to-face class where attendance and participation might be relegated to $10 \%$ of the course grade. Daily interaction with the students and weekly feedback of grades keeps the focus on the student's progress as an individual and as a member of the learning community. Multiple assessment methods is such an important point that we reinforce this point by calling it the UFO approach to online assessment, i.e., Unique Frequent Opportunities for cyber class assessment.

Figure 4

Cyberspace Assessment

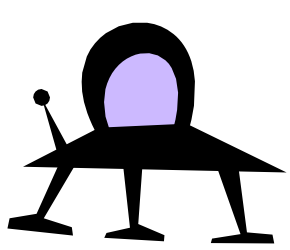

UNIQUE FREQUENT OPPORTUNITIES

Third, projects and term papers can be altered to fit the online environment. Course-specific and studentspecific assignments can also be used in the traditional environment but if one wants to clearly make the point that a preventive strategy is being used to prevent online dishonesty, idiosyncratic assignments lessen the lure of paper mills and other outside intervention. After all, if Sam Student has to write a paper that relates trends in corporate benefit plans to his own company, someone not working for that company is unlikely to want to spend the time on such a project. Professor \# 10, notably the one who has taught 150 undergraduate and graduate online courses, put it quite clearly when he said the following:

Students who cheat will do so no matter what form of course delivery is used. My approach is to use essentially the same testing assignments in both delivery formats. They require students to summarize some piece of academic literature, apply the topic of the research to their jobs, and provide recommendations as to how to improve their respective organizations based on what they learned from the reading. (Manyak, 2006, personal communication)

We end where we started by reiterating that online classes are here to stay and the service they provide is valuable and considerable. We also acknowledge that problems of academic integrity are everywhere and to deny that they exist in cyberspace is unrealistic. However, it seems unproductive to suggest that these problems are insurmountable and, indeed in the minds of some, a reason to not engage in online classes at all. The authors are committed to online instruction, but they believe cyberspace is not for everyone, neither faculty nor students. For faculty who are intrigued by this new delivery system, we urge you to proactively plan your assessment strategies, establish high standards, and lead your students on their journey through cyberspace. 


\section{REFERENCES}

1. BBC News (2000). Online degree courses double. BBC News Online. Retrieved August 26, 2006 from http://news.bbc.co.uk/2/hi/uk_news/education/681072.stm.

2. Cooper, S. (December, 2003). Hot biz: Online learning. Entrepreneur. Retrieved August 26, 2006 from http://www.findarticles.com/p/articles/mi_m0DTI/is_12_31/ai_111163610

3. Gibson, J. W., Blackwell, C. W., Greenwood, R. A., Mobley, I. \& Blackwell, R. W. (2006, in press). Preventing and detecting plagiarism in the written work of college students. Journal of Diversity Management.

4. Grijalva, T. C. (March, 2006). Academic honesty and online courses. College Student Journal. Retrieved July 27, 2006 from http://www.findarticles.com/p/articles/mi_mOFCR/is_1_40/ai_n16346361

5. Greenway, R. (Spring, 2006). The virtual revolution: understanding online schools. Education Next. Retrieved July 27, 2006 from http://www.findarticles.com/p/articles/mi_m0MJG/is_2_6/ai_n16118691

6. Heberling, M. (Spring, 2002). Maintaining academic integrity in online education. Online Journal of Distance Learning Administration, V(I). Retrieved 8/21/06 from http://www.westga.edu/ distance/ojdla/spring51/heberling51.html.

7. Kleiner, C. and Lord, M. (November 22, 1999). The cheating game: Everyone's doing it from grade school to graduate school. U.S. News \& World Reports. Retrieved August 26, 2006 from http://www.usnewsclassroom.com/issue/991122/cheating.htm

8. McCabe, D. L. (Summer/Fall 2005). It takes a village: Academic dishonesty \& educational opportunity. Liberal Education. Retrieved January 19. 2006 from www.findarticles.com.

9. Mujtaba, B. (August, 2006) Personal correspondence.

10. Olt, M. R. (Fall, 2002). Ethics and distance education: Strategies for minimizing academic dishonesty in online assessment. Online Journal of Distance Learning Administration, V(II). Retrieved on 8/21/06 from http://www.westga.edu/ distance/ojdla/fall53/olt3.html

11. PR Newswire (June 26, 2006). Virtual school leaders encourage growth of K-12 online learning; discuss high school reform at online summit. Forbes.com. Retrieved August 26, 2006 from http://www.forbes.com/prnewswire/feeds/prnewswire/2006/06/26/prnewswire200606261446PR_NEWS_B MAT_NY_NYM251.html

12. Roach, R. (June 7, 2001). Safeguarding against online cheating-Distance education standards and plagiarism. Black Issues in Higher Education. Retrieved 1/19/06 from www.findarticles.com.

13. Rowe, N. (Summer, 2004). Cheating in online student assessment: Beyond plagiarism. Online Journal of Distance Learning Administration, VII(II).

\section{NOTES}




\section{NOTES}

